\title{
Pertumbuhan Bibit Kelapa Sawit (Elais guineensis) pada Beberapa Waktu dan Arah Aplikasi Boron (B) dan Silikon (Si) Melalui Daun
}

\author{
DOI 10.18196/pt.2015.039.52-59
}

\author{
Ageng Kaloko*, Eka Tarwaca Susila, Didik Indra Dewa \\ Jurusan Budidaya Pertanian, Fakultas Pertanian, Universitas Gadjah Mada, \\ Jl. Flora, Bulaksumur, Depok, Sleman, Yogyakarta 55281, Indonesia, Telp./fax.: (0274) 563062, \\ *Corresponding author, e-mail: agengkaloko@gmail.com
}

\begin{abstract}
ABSTRAK
Penelitian ini bertujuan untuk mempelajari pengaruh pemberian B dan Si terhadap proses fisiologis dan pertumbuhan bibit kelapa sawit yang mengalami cekaman kekeringan serta mendapatkan cara dan waktu pemberian B dan Si yang efektif untuk mengurangi pengaruh kekeringan terhadap penurunan proses fisiologis dan pertumbuhan bibit kelapa sawit. Percobaan telah dilaksanakan di dusun Bendosari, Desa Madurejo, Kecamatan Prambanan, Kabupaten Sleman; Laboratorium IImu Tanaman Fakultas Pertanian UGM, Laboratorium Anatomi Tanaman Fakultas Biologi UGM dan Laboratorium Pengujian dan Penelitian Terpadu (LPPT) UGM di Yogyakarta pada bulan Maret - Desember 2012. Penelitian menggunakan rancangan acak kelompok lengkap (RAKL) faktorial dengan 3 blok sebagai ulangan. Faktor pertama adalah cara pemupukan, faktor kedua adalah waktu pemupukan. Data yang telah diperoleh selanjutnya dianalisis menggunakan Analisis Varian (ANOVA) pada level 5\%, dan dilanjutkan dengan uji beda nyata terkecil (LSD). Hasil penelitian menunjukkan bahwa serapan B meningkat secara nyata dengan aplikasi B pada daun melalui penyemprotan pada waktu pagi, siang dan sore hari melalui arah permukaan bawah, atas serta bawah+atas daun. Namun demikian, serapan Si hanya mampu meningkat apabila pupuk sumber Si diaplikasikan dengan cara penyemprotan pada daun melalui arah bawah dan atas permukaan daun di waktu sore hari. Bibit kelapa sawit dapat ditingkatkan ketahanannya terhadap cekaman kekeringan dengan indikasi berupa kenaikan skor kandungan lignin dan suberin dalam jaringan akar serta ukuran diameter batang jika dibandingkan dengan kontrol melalui aplikasi pupuk sumber B dan Si pada daun dengan cara penyemprotan pada waktu pagi, siang dan sore hari melalui arah permukaan bawah, atas serta bawah dan atas daun.

Kata kunci: Kelapa Sawit, Boron, Silicon, Waktu dan arah aplikasi, Pupuk daun
\end{abstract}

\begin{abstract}
Study entitled 'Growth and Drought Resistance Seed Oil Palm (Elaeis guineensis) in Multiple Time and Direction Applications Boron (B) and Silicon (Si) through Leaves' aims to study the effect of B and Si on physiological processes and growth of oil palm seedlings experiencing drought stress and get a way and timing of $B$ and Si is effective to reduce the effect of drought on the decline of physiological processes and growth of oil palm seedlings, Has been implemented in the hamlet Bendosari Madurejo village, Prambanan subdistrict, Sleman; Laboratory of Plant Sciences Faculty of Agriculture, Plant Anatomy Laboratory of the Faculty of Biology and Integrated Research and Testing Laboratory (LPPT) Gadjah Mada University Yogyakarta in March to December of 2012. Research using a complete randomized block design (RAKL) factorial $3 \times 31$ to 3 blocks as replications. The first factor is the way fertilization, the second factor is the time of fertilization and added a comparison (control) without any fertilization treatment. The data analyzed were obtained using Varian Analysis (ANOVA) at the level of 5\%, and followed by a test of least significant difference LSD. The results showed that the uptake and increased significantly with the application and the leaves by spraying in the morning, afternoon and evening through the direction of the bottom surface, the top and bottom of leaves. However, absorption of Si is only able to increase if the source of Si fertilizer applied by spraying the leaves through a downward direction on the surface of leaves in the evening. Oil palm seedlings can be improved resistance to drought stress with an indication of the form of increasing scores lignin and suberin in roots network as well as the size of the diameter of the rod when compared with control through the application of fertilizer source of $B$ and Si on the leaves by spraying in the morning, afternoon and evening through direction of the bottom surface, the top and bottom of leaves. Keywords: Palm oil, Drought, Boron, Silicon, Foliar fertilization
\end{abstract}

\section{PENDAHULUAN}

Rendahnya produktivitas dan upaya perbaikan peningkatan produktivitas dimasa mendatang dihadapkan pada berbagai kendala, teknis maupun non teknis. Kendala non teknis yang dialami oleh petani akhir-akhir ini adalah perubahan iklim global. Salah satu penyebab terjadinya perubahan iklim adalah pemanasan global oleh efek gas rumah kaca. Salah satu tanaman yang terkena dampak perubahan iklim adalah kelapa sawit. 
Perubahan iklim menyebabkan musim kemarau lebih panjang sehingga berpengaruh terhadap pertumbuhan terutama bibit kelapa sawit. Kualitas bibit kelapa sawit yang baik sangat penting dalam proses budidaya yang berpengaruh pada hasil. Cekaman kekeringan akan membuat hara yang dibutuhkan tanaman tidak dapat diserap dengan baik, sehingga diperlukan unsur hara dan metode pengaplikasiannya yang tepat.

Pengaplikasian boron dan silikon dapat digunakan sebagai alternatif untuk mengurangi dampak negatif cekaman kekeringan dan pemanasan terhadap pertumbuhan tanaman. Aplikasi $\mathrm{B}$ pada tanaman yang tercekam temperatur tinggi dan kekeringan memberikan pengaruh positif terhadap kekuatan dan stabilitas sel (Putra et al., 2011). Selain itu B dapat menstimulasi sintesis beberapa jenis antioksidan yang berperan untuk menghilangkan pengaruh ROS sehingga dapat menurunkan kerusakan oksidatif (Rodriguez et al., 2010). Aplikasi Si pada tanaman tercekam kekeringan dapat meningkatkan efisiensi penggunan air (Gao et al., 2004) dan meningkatkan aktivitas antioksidan (Crusciol et al., 2009). Lebih lajut dikemukakan bahwa Si dapat meningkatkan kandungan polisakarida pada dinding sel sehingga sel menjadi lebih kuat dan tidak mudah mengalami kerusakan (Putra et al., 2011) akibat temperatur tinggi dan cekaman kekeringan. Aplikasi Si pada tanaman tercekam kekeringan dapat meningkatkan efisiensi penggunan air (Gao et al., 2004) dan meningkatkan aktivitas antioksidan (Crusciol et al., 2009).

Penelitian ini bertujuan untuk mempelajari pengaruh pemberian B dan Si terhadap proses fisiologis dan pertumbuhan bibit kelapa sawit yang mengalami cekaman kekeringan serta mendapatkan cara dan waktu pemberian B dan Si yang efektif untuk mengurangi pengaruh kekeringan terhadap penurunan proses fisiologis dan pertumbuhan bibit kelapa sawit.

\section{BAHAN DAN METODE}

Penelitian dilaksanakan di dusun Bendosari, Desa Madurejo, Kecamatan Prambanan, Kabupaten Sleman; Laboratorium Ilmu Tanaman Fakultas Pertanian UGM, Laboratorium Anatomi Tanaman Fakultas Biologi UGM dan Laboratorium Pengujian dan Penelitian Terpadu (LPPT) UGM di Yogyakarta pada bulan Maret Desember 2012.

Alat-alat yang digunakan dalam penelitian meliputi: Spectronic 21D Milton Roy, spektrometer UV-VIS 1700, leaf area meter, mikroskop, optilab, Photosynthetic Analyzer type LI Cor LI 6400 , termohigrometer, lux meter, penetrometer, SPAD 502, grinder, timbangan, timbangan analitik, jangka sorong digital, meteran, labu takar, gelas ukur, beker gelas, gelas obyek, botol plastik gelap dan mikro pipet. Sedangkan bahanbahan yang digunakan meliputi: bibit kelapa sawit umur 5 bulan, top soil, polibag, pupuk NPK (15:15:15), kieserit, KCL, pestisida, boric acid $\left(\mathrm{H}_{3} \mathrm{BO}_{3}\right)$, sodium silikat $\left(\mathrm{Na}_{2} \mathrm{SiO}_{3}\right)$, FAA (formalin Acetic Acid Alcohol), phloroglucinol, etanol 80\% dan 95\%, HCl, Sudan Black B, Folin-Ciocalteu, $\mathrm{Na}_{2} \mathrm{CO}_{3}$, asam sulfosalisilat $3 \%$, kertas saring Whatman 2, asam ninhidrin, asam asetat glacial, toluen, aquabidestilata, aquades, asam galat, DPPH (2,2-diphenyl-1-picrylydrazyl), metanol, buffer phosphat pH 7.4 dan 7.5, hidrogen piroksida $\left(\mathrm{H}_{2} \mathrm{O}_{2}\right), \mathrm{NaNO} 3$, sulfanil amide $1 \%$, dan $\mathrm{N}$-naftil etilene diamide $0,02 \%$.

Penelitian menggunakan rancangan acak kelompok lengkap (RAKL) faktorial 3 x 3 dengan 3 blok sebagai ulangan. Faktor pertama adalah waktu pemupukan (A) dan faktor kedua adalah cara pemupukan (B). Setiap blok mempunyai 30 kombinasi perlakuan dan ditambah satu pembanding (kontrol) tanpa diberi perlakuan pemu- 
pukan. Pada penelitian ini digunakan boric acid $\left(\mathrm{H}_{3} \mathrm{BO}_{3}\right)$ sebagai sumber $\mathrm{B}$ serta sodium silicate $\left(\mathrm{Na}_{2} \mathrm{SiO}_{3}\right)$ sebagai sumber $\mathrm{Si}$.

Faktor waktu pemupukan terdiri atas:

A1: Pemupukan pagi hari (08.00)

A2: Pemupukan siang hari (12.00)

A3: Pemupukan sore hari (17.00)

Faktor cara pemupukan terdiri atas:

B1: pemupukan melalui bagian atas permukaan daun

B2: Pemupukan melalui bawah permukaan daun B3: Pemupukan secara random (kombinasi antara pemupukan melalui atas dan permukaan dain)

Variabel yang diamati selama penelitian ini antara lain kekuatan akar, Luas Permukaan Akar, panjang akar total, diameter akar, kekuatan akar, luas permukaan akar, panjang akar total, diameter akar. Hasil pengamatan kemudian dianalisis menggunakan uji anova, jika terdapat beda nyata maka akan diuji lanjut menggunakan LSD dengan taraf $5 \%$.

\section{HASIL DAN PEMBAHASAN}

Hasil pengamatan pada parameter kekuatan akar, Luas Permukaan Akar, panjang akar total, diameter akar setelah diberi pupuk B dan Si melalui daun sebelum dan sesudah mengalami cekaman kekeringan disajikan pada Tabel 1. Tabel 1 memberikan informasi bahwa tidak terdapat perbedaan yang nyata antara bibit kelapa sawit yang mendapatkan aplikasi B dan Si melalui daun dengan bibit yang tidak mendapatkan aplikasi B dan Si (kontrol) pada variabel kekuatan akar, dan diameter akar sebelum ataupun sesudah cekaman kekeringan. Kekuatan akar sebelum dan sesudah cekaman kekeringan sama besar pada semua perlakuan waktu aplikasi
B dan Si melalui daun yang diuji termasuk control, begitu juga dengan diameter akar (Tabel 1).

Tabel 1. Pengaruh Waktu Pemupukan B dan Si Melalui Daun terhadap Kekuatan Akar, Luas Permukaan Akar, Panjang Akar Total dan Diameter Akar Bibit Kelapa Sawit

\begin{tabular}{lcccc}
\hline \multirow{2}{*}{ Variabel Pengamatan } & \multicolumn{4}{c}{ Waktu Pemupukan B dan Si Melalui Daun } \\
\cline { 2 - 5 } & $\begin{array}{l}\text { Pagi hari } \\
(08.00)\end{array}$ & $\begin{array}{c}\text { Siang hari } \\
(12.00)\end{array}$ & $\begin{array}{c}\text { Sore hari } \\
(17.00)\end{array}$ & Kontrol \\
\hline Sebelum Cekaman Kekeringan & & & & \\
Kekuatan Akar (N) & $79,33 \mathrm{a}$ & $76,94 \mathrm{a}$ & $79,35 \mathrm{a}$ & $75,44 \mathrm{a}$ \\
Luas Permukaan Akar (cm²) & $989,60 \mathrm{ab}$ & $798,80 \mathrm{~b}$ & $1015,60 \mathrm{ab}$ & $1121,00 \mathrm{a}$ \\
Panjang Akar Total (cm) & $984,90 \mathrm{ab}$ & $871,90 \mathrm{~b}$ & $1051,30 \mathrm{ab}$ & $1202,20 \mathrm{a}$ \\
Diameter Akar (cm) & $0,33 \mathrm{a}$ & $0,31 \mathrm{a}$ & $0,34 \mathrm{a}$ & $0,30 \mathrm{a}$ \\
Sesudah Cekaman Kekeringan & & & & \\
Kekuatan Akar (N) & $84,67 \mathrm{a}$ & $88,03 \mathrm{a}$ & $88,25 \mathrm{a}$ & $87,27 \mathrm{a}$ \\
Luas Permukaan Akar (cm²) & $584,10 \mathrm{a}$ & $761,10 \mathrm{a}$ & $714,00 \mathrm{a}$ & $801,33 \mathrm{a}$ \\
Panjang Akar Total $(\mathrm{cm})$ & $608,10 \mathrm{a}$ & $839,60 \mathrm{a}$ & $800,50 \mathrm{a}$ & $775,70 \mathrm{a}$ \\
Diameter Akar $(\mathrm{cm})$ & $0,17 \mathrm{a}$ & $0,15 \mathrm{a}$ & $0,16 \mathrm{a}$ & $0,17 \mathrm{a}$ \\
\hline
\end{tabular}

Keterangan: Angka yang diikuti huruf yang berbeda menunjukkan ada beda nyata pada masing-masing perlakuan.

Sebelum terjadi kekeringan, panjang dan luas permukaan akar tidak dipengaruhi oleh aplikasi B dan Si bila diberikan pada pagi dan sore hari, namun menurun bila diberikan pada siang hari. Berbeda dengan sebelum kekeringan, sesudah tanaman mengalami kekeringan, pemberian $\mathrm{B}$ dan Si pagi hari tidak mempunyai pengaruh yang nyata.

Sebelum terjadi cekaman kekeringan, kekuatan akar berengaruh meningkat bila B dan Si disemprotkan dari atas permukaan daun, namun pada variabel panjang akar total pemberian $\mathrm{B}$ dan Si akan menurun bila disemprotkan dari atas permukaan daun. Kekuatan akar, luas permukaan akar, panjang akar, dan diameter akar bibit kelapa sawit setelah cekaman kekeringan yang mendapatkan aplikasi pupuk B dan Si melalui daun dari berbagai arah yang diuji menunjukkan hasil yang sama dengan kontrol. Kekuatan akar tertinggi sebelum cekaman kekeringan dicapai oleh aplikasi pemupukan B dan 
Si dari arah atas permukaan daun dan terendah dijumpai pada kontrol (Tabel 2).

Tabel 2. Pengaruh Arah Aplikasi Pupuk B dan Si Melalui Daun Terhadap Kekuatan Akar, Luas Permukaan Akar, Panjang Akar Total dan Diameter Akar Bibit Kelapa Sawit

\begin{tabular}{lcccc}
\hline & \multicolumn{4}{c}{ Arah Pemupukan B dan Si Melalui Daun } \\
\cline { 2 - 5 } Variabel Pengamatan & $\begin{array}{c}\text { Atas } \\
\text { Permukaan } \\
\text { Daun }\end{array}$ & $\begin{array}{c}\text { Bawah } \\
\text { Permukaan } \\
\text { Daun }\end{array}$ & $\begin{array}{c}\text { Atas + Bawah } \\
\text { Permukaan } \\
\text { Daun }\end{array}$ & Kontrol \\
\hline Sebelum Cekaman Kekeringan & & & & \\
Kekuatan Akar (N) & $80,35 \mathrm{a}$ & $77,99 \mathrm{ab}$ & $77,27 \mathrm{ab}$ & $75,44 \mathrm{~b}$ \\
Luas Permukaan Akar (cm²) & $887,80 \mathrm{a}$ & $1024,50 \mathrm{a}$ & $891,70 \mathrm{a}$ & $1121,00 \mathrm{a}$ \\
Panjang Akar Total (cm) & $826,60 \mathrm{~b}$ & $1152,50 \mathrm{ab}$ & $929,00 \mathrm{ab}$ & $1202,19 \mathrm{a}$ \\
Diameter Akar (cm) & $0,37 \mathrm{a}$ & $0,28 \mathrm{~b}$ & $0,32 \mathrm{ab}$ & $0,30 \mathrm{ab}$ \\
Sesudah Cekaman Kekeringan & & & & \\
Kekuatan Akar (N) & $88,52 \mathrm{a}$ & $84,32 \mathrm{a}$ & $88,11 \mathrm{a}$ & $87,27 \mathrm{a}$ \\
Luas Permukaan Akar (cm²) & $663,40 \mathrm{a}$ & $721,30 \mathrm{a}$ & $674,40 \mathrm{a}$ & $801,30 \mathrm{a}$ \\
Panjang Akar Total (cm) & $788,10 \mathrm{a}$ & $727,90 \mathrm{a}$ & $732,20 \mathrm{a}$ & $775,70 \mathrm{a}$ \\
Diameter Akar $(\mathrm{cm})$ & $0,15 \mathrm{a}$ & $0,16 \mathrm{a}$ & $0,17 \mathrm{a}$ & $0,17 \mathrm{a}$ \\
\hline
\end{tabular}

Keterangan: Huruf yang berbeda dibelakang angka pada baris yang sama menunjukkan ada beda nyata pada masing-masing perlakuan nilai yang diikuti huruf yang sama, untuk masing-masing variabel pengamatan sebelum dan sesudah kekeringan, tidak berbeda nyata dengan LSD jenjang $5 \%$

Diduga, setelah bibit kelapa sawit terekspos oleh cekaman kekeringan, deposit lignin dan suberin di perakaran dibongkar kembali untuk memenuhi kebutuhan bahan kering tanaman khususnya di bagian tajuk kelapa sawit untuk tetap mempertahankan pertumbuhan tajuknya.

Oleh karena itu, bibit kelapa sawit yang memiliki cadangan lignin dan suberin lebih banyak pada jaringan perakarannya memiliki pertumbuhan tajuk yang lebih kuat saat tercekam kekeringan dibandingkan dengan bibit kelapa sawit yang kurang memiliki cadangan lignin dan suberin.

Pemupukan B pada bibit kelapa sawit pada waktu pagi, siang dan sore hari dapat meningkatkan kandungan B jika dibandingkan dengan kontrol, namun demikian kandungan Si dalam jaringan daun bibit kelapa sawit relatif tidak terpengaruh (Tabel 3). Pemupukan yang dilakukan pada sore hari menyebabkan kandungan B dalam jaringan daun bibit kelapa sawit lebih tinggi jika dibandingkan dengan pemupukan pada pagi maupun siang hari. Pemupukan B dan Si dari arah bawah, atas, bawah+atas permukaan daun dapat meningkatkan B dalam jaringan daun bibit kelapa sawit jika dibandingkan dengan kontrol, namun demikian situasi tersebut tidak berlaku bagi kandungan Si. Kandungan Si dalam jaringan daun bibit kelapa sawit relatif menurun jika pengaplikasian B dan Si diberikan melalui permukaan atas daun (Tabel 3). Pemupukan B dan Si dari arah atas permukaan daun menyebabkan kandungan B dalam jaringan daun bibit kelapa sawit tertinggi disusul pemupukan dari arah atas+bawah dan bawah permukaan daun.

Tabel 3. Pengaruh Waktu dan Arah Pemupukan B dan Si Melalui Daun terhadap Kandungan B dan Si Bibit Kelapa Sawit

\begin{tabular}{lcccc}
\hline \multirow{2}{*}{ Variabel Pengamatan } & \multicolumn{4}{c}{ Waktu Pemupukan } \\
\cline { 2 - 5 } & $\begin{array}{c}\text { Pagi hari } \\
(08.00)\end{array}$ & $\begin{array}{c}\text { Siang hari } \\
(12.00)\end{array}$ & $\begin{array}{c}\text { Sore hari } \\
(17.00)\end{array}$ & Kontrol \\
\hline B (ppm) & 263,67 & 255,67 & 274,00 & 69,00 \\
Si (ppm) & 0,57 & 0,72 & 1,46 & 1,00 \\
\cline { 2 - 5 } & \multicolumn{5}{c}{ Arah Pemupukan } \\
\cline { 2 - 5 } & Atas Daun & Bawah Daun & Atas + Bawah Daun & Kontrol \\
\hline B (ppm) & 270,67 & 249,33 & 273,33 & 69,00 \\
Si (ppm) & 0,76 & 0,86 & 1,12 & 1,00 \\
\hline
\end{tabular}

Tabel 3 memberikan informasi bahwa beberapa perlakuan menyebabkan kandungan B dalam jaringan daun $>250 \mathrm{ppm}$. Kandungan B dalam jaringan yang mencapai lebih dari 250 ppm sudah bersifat racun bagi tanaman, sejalan dengan pendapat Tanaka dan Fujiwara (2007). Translokasi $\mathrm{B}$ dari akar mengikuti aliran transpirasi yang kemudian terakumulasi di daun terutama di ujung dan tepi daun.Nable et al. (1997) menyebutkan bahwa dalam kondisi normal kandungan B dalam jaringan daun berkisar 40 - 100 ppm dan tanaman mulai mengalami keracunan pada kadar B sebesar 250 ppm. 
Tabel 4. Pengaruh Waktu Pemupukan B dan Si Melalui Daun terhadap Panjang, Lebar dan Jumlah Stomata Bibit Kelapa Sawit

\begin{tabular}{lcccc}
\hline \multirow{2}{*}{ Variabel Pengamatan } & \multicolumn{4}{c}{ Waktu Pemupukan } \\
\cline { 2 - 5 } & $\begin{array}{c}\text { Pagi hari } \\
(08.00)\end{array}$ & $\begin{array}{c}\text { Siang hari } \\
(12.00)\end{array}$ & $\begin{array}{c}\text { Sore hari } \\
(17.00)\end{array}$ & Kontrol \\
\hline Sebelum Cekaman Kekeringan & & & & \\
Panjang Stomata $(\mu \mathrm{m})$ & $5,77 \mathrm{a}$ & $5,85 \mathrm{a}$ & $7,04 \mathrm{a}$ & $6,89 \mathrm{a}$ \\
Lebar Stomata $(\mu \mathrm{m})$ & $6,59 \mathrm{a}$ & $6,16 \mathrm{a}$ & $6,72 \mathrm{a}$ & $6,55 \mathrm{a}$ \\
Jumlah Stomata (buah) & $17,99 \mathrm{a}$ & $17,66 \mathrm{a}$ & $17,06 \mathrm{a}$ & $16,76 \mathrm{a}$ \\
Sesudah Cekaman Kekeringan & & & & \\
Panjang Stomata (mm) & $27,89 \mathrm{a}$ & $26,26 \mathrm{a}$ & $28,63 \mathrm{a}$ & $28,56 \mathrm{a}$ \\
Lebar Stomata (mm) & $6,46 \mathrm{a}$ & $5,87 \mathrm{a}$ & $6,46 \mathrm{a}$ & $6,51 \mathrm{a}$ \\
Jumlah Stomata (buah) & $18,76 \mathrm{a}$ & $19,28 \mathrm{a}$ & $19,15 \mathrm{a}$ & $18,33 \mathrm{a}$ \\
\hline
\end{tabular}

Keterangan: Huruf yang berbeda dibelakang angka pada baris yang sama menunjukkan ada beda nyata pada masing-masing perlakuan nilai yang diikuti huruf yang sama, untuk masing-masing variabel pengamatan sebelum dan sesudah kekeringan, tidak berbeda nyata dengan DMRT jenjang $5 \%$

Panjang, lebar dan jumlah stomata tidak dipengaruhi oleh waktu aplikasi B dan Si melalui daun, sebelum dan sesudah periode cekaman kekeringan (Tabel 4). Tabel 4 juga menunjukkan bahwa panjang dan jumlah stomata setelah periode cekaman kekeringan lebih tinggi jika dibandingkan dengan sebelum periode cekaman kekeringan, namun demikian hal ini tidak berlaku pada variabel lebar bukaan stomata. Lebar bukaan stomata justru menurun pada periode cekaman kekeringan.

Tabel 5. Pengaruh Arah Pemupukan B dan Si Melalui Daun terhadap Panjang, Lebar dan Jumlah Stomata Bibit Kelapa Sawit

\begin{tabular}{lcccc}
\hline \multirow{2}{*}{ Variabel Pengamatan } & \multicolumn{4}{c}{ Arah Pemupukan } \\
\cline { 2 - 5 } & Atas Daun & Bawah Daun & $\begin{array}{c}\text { Atas + Bawah } \\
\text { Daun }\end{array}$ & Kontrol \\
\hline Sebelum Cekaman Kekeringan & & & & \\
Panjang Stomata $(\mu \mathrm{m})$ & $7,00 \mathrm{a}$ & $5,52 \mathrm{a}$ & $6,15 \mathrm{a}$ & $6,89 \mathrm{a}$ \\
Lebar Stomata $(\mu \mathrm{m})$ & $6,72 \mathrm{a}$ & $6,97 \mathrm{a}$ & $5,87 \mathrm{a}$ & $6,55 \mathrm{a}$ \\
Jumlah Stomata (buah) & $17,93 \mathrm{a}$ & $16,88 \mathrm{a}$ & $17,89 \mathrm{a}$ & $16,76 \mathrm{a}$ \\
Sesudah Cekaman Kekeringan & & & & \\
Panjang Stomata (mm) & $27,96 \mathrm{a}$ & $27,15 \mathrm{a}$ & $27,67 \mathrm{a}$ & $28,56 \mathrm{a}$ \\
Lebar Stomata (mm) & $6,54 \mathrm{a}$ & $6,41 \mathrm{a}$ & $5,97 \mathrm{a}$ & $6,51 \mathrm{a}$ \\
Jumlah Stomata (buah) & $19,74 \mathrm{a}$ & $18,62 \mathrm{a}$ & $18,83 \mathrm{a}$ & $18,33 \mathrm{a}$ \\
\hline
\end{tabular}

Keterangan: Huruf yang berbeda dibelakang angka pada baris yang sama menunjukkan ada beda nyata pada masing-masing perlakuan nilai yang diikuti huruf yang sama, untuk masing-masing variabel pengamatan sebelum dan sesudah kekeringan, tidak berbeda nyata dengan DMRT jenjang $5 \%$.
Arah aplikasi B dan Si melalui daun tidak berpengaruh nyata terhadap panjang, lebar dan jumlah stomata, periode sebelum maupun setelah cekaman kekeringan (Tabel 5). Pemupukan B dan Si melalui daun dari berbagai arah menyebabkan panjang, lebar dan jumlah stomata pada daun bibit kelapa sawit nilainya sama besar jika dibandingkan dengan kontrol. Panjang dan jumlah stomata setelah periode cekaman kekeringan lebih tinggi jika dibandingkan dengan periode sebelum cekaman kekeringan. Namun demikian, hal tersebut tidak terjadi pada variabel lebar bukaan stomata (Tabel 5).

Tabel 6. Pengaruh Waktu Pemupukan B dan Si Melalui Daun terhadap Berat Kering, Bdk dan Nld Bibit Kelapa Sawit

\begin{tabular}{lcccc}
\hline \multirow{2}{*}{ Variabel Pengamatan } & \multicolumn{4}{c}{ Waktu Pemupukan } \\
\cline { 2 - 5 } & $\begin{array}{c}\text { Pagi hari } \\
(08.00)\end{array}$ & $\begin{array}{c}\text { Siang hari } \\
(12.00)\end{array}$ & $\begin{array}{c}\text { Sore hari } \\
(17.00)\end{array}$ & Kontrol \\
\hline Sebelum Cekaman Kekeringan & & & & \\
Berat Kering Total (g) & $38,11 \mathrm{a}$ & $44,48 \mathrm{a}$ & $41,85 \mathrm{a}$ & $45,06 \mathrm{a}$ \\
Berat Kering Tajuk (g) & $26,99 \mathrm{a}$ & $26,63 \mathrm{a}$ & $30,14 \mathrm{a}$ & $30,49 \mathrm{a}$ \\
Berat kering akar (g) & $11,12 \mathrm{a}$ & $13,56 \mathrm{a}$ & $12,09 \mathrm{a}$ & $14,57 \mathrm{a}$ \\
BDK & $0,53 \mathrm{a}$ & $0,62 \mathrm{a}$ & $0,57 \mathrm{a}$ & $0,58 \mathrm{a}$ \\
NLD & $0,57 \mathrm{ab}$ & $0,57 \mathrm{ab}$ & $0,67 \mathrm{a}$ & $0,50 \mathrm{~b}$ \\
Sesudah Cekaman Kekeringan & & & & \\
Berat kering total (g) & $43,83 \mathrm{c}$ & $54,07 \mathrm{~b}$ & $49,34 \mathrm{bc}$ & $62,41 \mathrm{a}$ \\
Berat kering tajuk (g) & $23,49 \mathrm{a}$ & $27,72 \mathrm{a}$ & $29,4 \mathrm{a}$ & $36,85 \mathrm{a}$ \\
Berat kering akar (g) & $20,34 \mathrm{a}$ & $20,67 \mathrm{a}$ & $22,18 \mathrm{a}$ & $25,56 \mathrm{a}$ \\
BDK & $1,26 \mathrm{a}$ & $1,11 \mathrm{a}$ & $1,17 \mathrm{a}$ & $1,18 \mathrm{a}$ \\
NLD & $0,27 \mathrm{a}$ & $0,28 \mathrm{a}$ & $0,30 \mathrm{a}$ & $0,28 \mathrm{a}$ \\
\hline
\end{tabular}

Keterangan: Huruf yang berbeda dibelakang angka pada baris yang sama menunjukkan ada beda nyata pada masing-masing perlakuan nilai yang diikuti huruf yang sama, untuk masing-masing variabel pengamatan sebelum dan sesudah kekeringan, tidak berbeda nyata dengan LSD jenjang $5 \%$.

Tabel 6 memberikan informasi bahwa bibit kelapa sawit yang mendapatkan aplikasi B dan Si melalui daun setara dengan kontrol pada variabel berat kering tanaman dan berat daun khas sebelum cekaman kekeringan. Variabel berat kering total mengalami penurun yang nyata pada semua waktu pengaplikasian B dan Si dibandingkan kontroln pada periode sesudah ceka- 
man kekeringan. Hal ini tidak dijumpai pada nisbah luas daun setelah cekaman kekeringan yang cenderung setara dengan kontrol. Namun demikian, nisbah luas daun bibit kelapa sawit yang mendapatkan aplikasi B dan Si melalui daun lebih tinggi jika dibandingkankan kontrol pada periode sebelum cekaman kekeringan.

Tabel 6 menunjukkan bahwa berat kering sebelum cekaman kekeringan, BDK dan NLD sebelum dan sesudah cekaman kekeringan tidak dipengaruhi oleh aplikasi B dan Si melalui daun. Berat kering tanaman setelah cekaman kekeringan tertinggi ditunjukkan oleh kontrol dan terendah ditunjukkan oleh aplikasi pupuk B dan Si melalui daun pada pagi hari.

Tabel 7. Pengaruh Arah Pemupukan B dan Si Melalui Daun terhadap Berat Kering, Bdk dan Nld Bibit Kelapa Sawit

\begin{tabular}{lcccc}
\hline \multirow{2}{*}{ Variabel Pengamatan } & \multicolumn{4}{c}{ Arah Pemupukan } \\
\cline { 2 - 5 } & Atas Daun & Bawah Daun & $\begin{array}{c}\text { Atas + Bawah } \\
\text { Daun }\end{array}$ & Kontrol \\
\hline Sebelum Cekaman Kekeringan & & & & \\
Berat kering tanaman (g) & $38,70 \mathrm{a}$ & $39,79 \mathrm{a}$ & $45,96 \mathrm{a}$ & $45,06 \mathrm{a}$ \\
Berat kering tajuk (g) & $20,51 \mathrm{a}$ & $21,9 \mathrm{a}$ & $26,92 \mathrm{a}$ & $30,49 \mathrm{a}$ \\
Berat kering akar (g) & $18,19 \mathrm{a}$ & $17,89 \mathrm{a}$ & $19,04 \mathrm{a}$ & $14,57 \mathrm{a}$ \\
BDK & $0,56 \mathrm{a}$ & $0,56 \mathrm{a}$ & $0,59 \mathrm{a}$ & $0,58 \mathrm{a}$ \\
NLD & $0,54 \mathrm{~b}$ & $0,58 \mathrm{ab}$ & $0,69 \mathrm{a}$ & $0,50 \mathrm{~b}$ \\
Sesudah Cekaman Kekeringan & & & & \\
Berat kering tanaman (g) & $46,79 \mathrm{~b}$ & $53,54 \mathrm{~b}$ & $46,91 \mathrm{~b}$ & $62,41 \mathrm{a}$ \\
Berat kering tajuk (g) & $28,93 \mathrm{a}$ & $35,31 \mathrm{a}$ & $29,57 \mathrm{a}$ & $36,85 \mathrm{a}$ \\
Berat kering akar (g) & $17,86 \mathrm{a}$ & $18,23 \mathrm{a}$ & $17,34 \mathrm{a}$ & $25,56 \mathrm{a}$ \\
BDK & $1,26 \mathrm{a}$ & $1,11 \mathrm{a}$ & $1,17 \mathrm{a}$ & $1,18 \mathrm{a}$ \\
NLD & $0,28 \mathrm{a}$ & $0,28 \mathrm{a}$ & $0,30 \mathrm{a}$ & $0,28 \mathrm{a}$ \\
\hline
\end{tabular}

Keterangan: Huruf yang berbeda dibelakang angka pada baris yang sama menunjukkan ada beda nyata pada masing-masing perlakuan nilai yang diikuti huruf yang sama, untuk masing-masing variabel pengamatan sebelum dan sesudah kekeringan, tidak berbeda nyata dengan LSD jenjang $5 \%$

Berat kering tanaman sebelum cekaman kekeringan tertinggi ditunjukkan oleh aplikasi pupuk B dan Si melalui daun dari permukaan atas+bawah daun namun tidak berbeda nyata dengan kontrol.Aplikasi B dan Si melalui daun dari permukaan atas daun memberikan berat kering terendah namun tidak berbeda nyata dengan pemupukan B dan Si melalui daun dari permukaan bawah daun (Tabel 7).

Bibit kelapa sawit yang mendapatkan perlakuan kontrol biomasanya lebih berat jika dibandingkan dengan bibit yang mendapatkan aplikasi pupuk B dan Si melalui daun, namun tidak berbeda nyata dengan aplikasi pupuk B dan Si melalui daun dari arah atas+bawah permukaan daun sebelum periode cekaman kekeringan (Tabel 7). Berat daun khas menunjukkan nilai yang tidak berbeda nyata pada semua perlakuan baik pada saat sebelum dan sesudah cekaman kekeringan. Nisbah luas daun sebelum dan sesudah cekaman kekeringan menunjukkan nilai yang tidak berbeda nyata, kecuali NLD pada periode sebelum cekaman kekeringan dimana NLD mengalami peningkatan pada aplikasi B dan Si melalui daun dari arah atas+bawah permukaan daun (Tabel 7).

Berat kering bibit kelapa sawit yang mendapatkan aplikasi B dan Si melalui daun lebih rendah jika dibandingkan dengan kontrol pada periode sesudah cekaman kekeringan (Tabel 6 dan 7). Hal ini disebabkan karena bibit kelapa sawit yang mendapatkan aplikasi B melalui daun mengalami keracunan B sehingga kemampuan fotosintesisnyalebih rendah jika dibandingkan dengan kontrol. Dampak keracunan B lebih terlihat pada bibit kelapa sawit yang mengalami cekaman kekeringan karena kadar B dalam jaringan menjadi lebih tinggi ketika tercekam kekeringan. Kandungan B dalam jaringan yang mencapai lebih dari $250 \mathrm{ppm}$ sudah bersifat racun bagi tanaman, sejalan dengan pendapat Tanaka dan Fujiwara (2007). Translokasi B dari akar mengikuti aliran transpirasi yang kemudian terakumulasi di daun terutama di ujung dan tepi daun Nable et al. (1997) menyebutkan bahwa dalam kondisi normal kandungan $\mathrm{B}$ dalam 
jaringan daun berkisar 40 - 100 ppm dan tanaman mulai mengalami keracunan pada kadar B sebesar 250 ppm.

Tabel 8. Pengaruh Waktu Pemupukan B dan Si Melalui Daun terhadap Konduktansi Stomata, Laju Transpirasi dan Fotosintesis Bibit Kelapa Sawit

\begin{tabular}{|c|c|c|c|c|}
\hline \multirow{2}{*}{ Variabel Pengamatan } & \multicolumn{4}{|c|}{ Waktu Pemupukan } \\
\hline & $\begin{array}{l}\text { Pagi hari } \\
(08.00)\end{array}$ & $\begin{array}{l}\text { Siang hari } \\
(12.00)\end{array}$ & $\begin{array}{c}\text { Sore hari } \\
(17.00)\end{array}$ & Kontrol \\
\hline \multicolumn{5}{|c|}{ Sebelum Cekaman Kekeringan } \\
\hline $\begin{array}{l}\text { Konduktansi stomata } \\
\left(\mathrm{mmol} \mathrm{H}_{2} \mathrm{O} / \mathrm{cm}^{2} \mathrm{~s}\right)\end{array}$ & $0,03 \mathrm{~b}$ & $0,04 \mathrm{~b}$ & $0,08 a$ & $0,04 \mathrm{~b}$ \\
\hline $\begin{array}{l}\text { Laju transpirasi } \\
\left(\mathrm{mmol} \mathrm{H}_{2} \mathrm{O} / \mathrm{cm}^{2} \mathrm{~s}\right)\end{array}$ & $0,81 \mathrm{~b}$ & $1,46 \mathrm{ab}$ & $2,48 \mathrm{a}$ & $1,35 \mathrm{ab}$ \\
\hline $\begin{array}{l}\text { Laju fotosintesis } \\
\left(\mu \mathrm{mol} \mathrm{CO}_{2} / \mathrm{cm}^{2} \mathrm{~s}\right)\end{array}$ & $45,99 \mathrm{~b}$ & $47,65 \mathrm{~b}$ & $52,36 b$ & $76,33 \mathrm{a}$ \\
\hline \multicolumn{5}{|c|}{ Sesudah Cekaman Kekeringan } \\
\hline $\begin{array}{l}\text { Konduktansi stomata } \\
\left(\mathrm{mmol} \mathrm{H}_{2} \mathrm{O} / \mathrm{cm}^{2} \mathrm{~s}\right)\end{array}$ & $6,11 \mathrm{a}$ & $5,37 \mathrm{ab}$ & $6,67 a$ & $3,44 b$ \\
\hline $\begin{array}{l}\text { Laju transpirasi } \\
\left(\mathrm{mmol} \mathrm{H}_{2} \mathrm{O} / \mathrm{cm}^{2} \mathrm{~s}\right)\end{array}$ & $4,85 b$ & $3,96 b$ & $6,88 a$ & $4,89 \mathrm{~b}$ \\
\hline $\begin{array}{l}\text { Laju fotosintesis } \\
\left(\mu \mathrm{mol} \mathrm{CO}_{2} / \mathrm{cm}^{2} \mathrm{~s}\right)\end{array}$ & $305,59 a b$ & $305,15 a b$ & $298,59 b$ & $317,33 \mathrm{a}$ \\
\hline
\end{tabular}

Keterangan: Huruf yang berbeda dibelakang angka pada baris yang sama menunjukkan ada beda nyata pada masing-masing perlakuan nilai yang diikuti huruf yang sama, untuk masing-masing variabel pengamatan sebelum dan sesudah kekeringan, tidak berbeda nyat dengan LSD jenjang $5 \%$.

Konduktansi stomata bibit kelapa sawit pada periode sebelum kekeringan dipengaruhi secara nyata oleh aplikasi B dan Si melalui daun pada waktu sore hari. Laju fotosintesis bibit kelapa sawit dipengaruhi secara nyata oleh aplikasi pupuk B dan Si melalui daun pada berbagai waktu, sebelum periode cekaman kekeringan (Tabel 8). Konduktansi stomata dan laju transpirasi tertinggi sebelum dan setelah periode cekaman kekeringan dimiliki oleh bibit kelapa sawit yang mendapatkan aplikasi B dan Si melalui daun pada sore hari. Aplikasi B dan Si melalui daun pada sore hari secara nyata mampu meningkatkan konduktansi stomata dan laju transpirasi bibit kelapa sawit.

Tabel 9 mengindikasikan bahwa laju fotosintesis bibit kelapa sawit yang mendapatkan aplikasi B dan Si melalui daun cendrung menurun dari kontrol, sebelum ataupun sesudah periode cekaman kekeringan. Secara individual, bibit kelapa sawit kontrol memiliki laju fotosintesis yang lebih tinggi jika dibandingkan dengan aplikasi B dan Si pada pagi, siang maupun sore hari sebelum periode cekaman kekeringan. $\mathrm{Na}$ mun demikian, setelah periode cekaman kekeringan laju fotosintesis bibit kelapa sawit yang mendapatkan aplikasi B dan Si pada pagi, siang maupun sore hari meningkat. Tabel 9 juga memberikan informasi bahwa laju fotosintesis bibit kelapa sawit kontrol lebih tinggi jika dibandingkan dengan aplikasi B dan Si melalui arah atas, bawah maupun atas+bawah permukaan daun sebelum periode cekaman kekeringan. Setelah periode cekaman kekeringan, laju fotosintesis bibit kelapa sawit yang mendapatkan aplikasi B dan Si melalui permukaan bawah daun meningkat sehingga setara dengan kontrol.

Tabel 9. Pengaruh Arah Pemupukan B dan Si Melalui Daun terhadap Konduktansi Stomata, Laju Transpirasi dan Fotosintesis Bibit Kelapa Sawit

\begin{tabular}{|c|c|c|c|c|}
\hline \multirow{2}{*}{ Variabel Pengamatan } & \multicolumn{4}{|c|}{ Arah Pemupukan } \\
\hline & Atas Daun & Bawah Daun & $\begin{array}{c}\text { Atas + Bawah } \\
\text { Daun }\end{array}$ & Kontrol \\
\hline \multicolumn{5}{|c|}{ Sebelum Cekaman Kekeringan } \\
\hline $\begin{array}{l}\text { Konduktansi stomata } \\
\left(\mathrm{mmol} \mathrm{H}_{2} \mathrm{O} / \mathrm{cm}^{2} \mathrm{~s}\right)\end{array}$ & $0,07 a$ & $0,02 \mathrm{~b}$ & $0,03 \mathrm{~b}$ & $0,04 \mathrm{~b}$ \\
\hline $\begin{array}{l}\text { Laju transpirasi } \\
\left(\mathrm{mmol} \mathrm{H}_{2} \mathrm{O} / \mathrm{cm}^{2} \mathrm{~s}\right)\end{array}$ & $1,93 \mathrm{a}$ & $0,91 \mathrm{~b}$ & $0,99 \mathrm{~b}$ & $1,35 a b$ \\
\hline $\begin{array}{l}\text { Laju fotosintesis } \\
\left(\mu \mathrm{mol} \mathrm{CO} / \mathrm{cm}^{2} \mathrm{~s}\right)\end{array}$ & $48,68 \mathrm{~b}$ & $50,37 \mathrm{~b}$ & $46,97 \mathrm{~b}$ & $76,33 a$ \\
\hline \multicolumn{5}{|c|}{ Sesudah Cekaman Kekeringan } \\
\hline $\begin{array}{l}\text { Konduktansi stomata } \\
\left(\mathrm{mmol} \mathrm{H}_{2} \mathrm{O} / \mathrm{cm}^{2} \mathrm{~s}\right)\end{array}$ & $6,26 \mathrm{a}$ & $6,04 \mathrm{~b}$ & $5,85 a b$ & $3,44 \mathrm{~b}$ \\
\hline $\begin{array}{l}\text { Laju transpirasi } \\
\left(\mathrm{mmol} \mathrm{H}_{2} \mathrm{O} / \mathrm{cm}^{2} \mathrm{~s}\right)\end{array}$ & $6,88 a$ & $4,93 \mathrm{~b}$ & $411 b$ & $4,66 \mathrm{~b}$ \\
\hline $\begin{array}{l}\text { Laju fotosintesis } \\
\left(\mu \mathrm{mol} \mathrm{CO}_{2} / \mathrm{cm}^{2} \mathrm{~s}\right)\end{array}$ & $299,55 b$ & $305,26 a b$ & $304,52 \mathrm{~b}$ & $\begin{array}{c}317,33 \\
a\end{array}$ \\
\hline
\end{tabular}

Keterangan: Huruf yang berbeda dibelakang angka pada baris yang sama menunjukkan ada beda nyata pada masing-masing perlakuan nilai yang diikuti huruf yang sama, untuk masing-masing variabel pengamatan sebelum dan sesudah kekeringan, tidak berbeda nyata dengan LSD jenjang $5 \%$.

Tabel 9 memberikan informasi bahwa konduktansi stomata bibit kelapa sawit secara nyata dipengaruhi oleh arah aplikasi B dan Si melalui permukaan atas daun, sebelum dan setelah peri- 
ode cekaman kekeringan dibandingkan kontrol. Bibit kelapa sawit yang mendapatkan aplikasi B dan Si melalui daun dari arah atas memiliki konduktansi stomata dan laju transpirasi yang tertinggi jika dibandingkan dengan perlakuan lainnya termasuk kontrol, sebelum dan setelah periode cekaman kekeringan. Sedangkan aplikasi B dan Si melalui daun dari arah bawah dan atas+bawah tidak berpengaruh terhadap konduktansi stomata dan laju transpirasi bibit kelapa sawit jika dibandingkan dengan kontrol, pada periode sebelum dan setelah cekaman kekeringan.

\section{SIMPULAN}

Serapan B meningkat secara nyata dengan aplikasi B pada daun melalui penyemprotan pada waktu pagi, siang dan sore hari melalui arah permukaan bawah, atas serta bawah+atas daun. Namun demikian, serapan Si hanya mampu meningkat apabila pupuk sumber Si diaplikasikan dengan cara penyemprotan pada daun melalui arah bawah+atas permukaan daun di waktu sore hari.

Pemberian pupuk Si dan B tidak berpengaruh secara nyata terhadap luas permukaan akar, panjang akar, diameter akar, panjang stomata, lebar stomata dan jumlah stomata. Namun pemberian pupuk Si dan B memiliki pengaruh yang nyata apabila pemberian pupuk dilakukan melalui atas daun.

\section{DAFTAR PUSTAKA}

Crusciol, C.A.C., Pulz, A.L., Lemos, L.B., Soratto, R.P. and Lima, G.P.P. 2009. Effects of silicon and drought stress on tuber yield and leaf biochemical charecteristics in potato. Crop Physiology and Metabolism 49: 949 - 954.

Gao, X.Q., Ohlander, M., Jeppsson, N., Bjork, L., Trajkovski, V., 2004.Changes in antioxidant effects and their relationshipto phytonutrients in fruits of sea buckthorn (Hippophaerhamnoides L.) during maturation.J. Agric. Food Chem. 48,14851490.
Nable, R. O.G.S. Banuelos and J.G. Paull. 1997. Breeding for Drought Resistance in Rice Physiology and Molecullar genetic Considerative. Crop Science 37: 1426-1434.

Putra, E.T.S., Zakaria, W., Abdullah, N.A.P and Saleh, G. 2011. Cell development of Musa sp. cv. Rastali fruit in relation to magnesium, boron and silicon availability. Malaysian Journal of Microscopy (In Press).

Rodriguez, M.G.H., Fontes, A.G., Rexach, J., Cristobal, J..C., Maldonado, J.M. and Gochicoa, M.T.N. 2010. Role of boron in vascular plants and response mechanisms to boron stresses. Plant Stress 4(2): 115 - 122.

Tanaka, M. and T. Fujiwara. 2007. Physiological Roles and Transport Mechanisms of Boron : Prespectives from Plants. Pflugers Arch- Eur J. Physiol 456: 671-677. 